Beata Springer

Uniwersytet Zielonogórski

\title{
Konsultacje społeczne jako forma demokratycznej partycypacji mieszkańców w zarządzaniu wspólnotą lokalną
}

DOI: $10.19195 / 1643-0328.21 .9$

Słowa kluczowe: partycypacja obywatelska, konsultacje społeczne, uchwała w sprawie konsultacji społecznych, współzarządzanie, dialog społeczny, standardy konsultacji społecznych

\section{Istota konsultacji społecznych — rozwiązania formalnoprawne}

W polskim systemie prawa konsultacje społeczne mają długą historię, a zaczątków tej instytucji należy doszukiwać się w okresie PRL. Najpierw — gdy w 1976 roku znowelizowano konstytucję z 1952 roku, określając w art. 86, iż: „Obywatele Polskiej Rzeczypospolitej Ludowej uczestniczą w sprawowaniu kontroli społecznej, w konsultacjach i dyskusjach nad węzłowymi problemami rozwoju kraju oraz zgłaszają wnioski”. Następnie - gdy uchwalono ustawę z dnia 6 maja 1987 roku o konsultacjach społecznych i referendum (Dz.U. Nr 14, poz. 83), która moc prawną utraciła 8 września 1995 roku. Obowiązywała więc sześć lat, w nowym ustroju nie mając jednakże praktycznego znaczenia. Była fasadą w niedemokratycznym ustroju, po 1989 roku zaś mimo zmiany systemu nie doczekała się realizacji w praktyce. Również przepis konstytucji lipcowej był fikcją, biorąc pod uwagę obowiązujący wówczas reżim polityczny.

Konsultacje są instytucją demokracji bezpośredniej, mechanizmem, który pozwala włączyć mieszkańców w proces podejmowania decyzji i uzyskać odpowiedź na pytanie, co stanowi istotne kwestie dla społeczności lokalnych. To mieszkańcy, uczestnicząc w konsultacjach, mają szanse wpływać na poprawę jakości swojego życia. Mogą uświadomić lokalnym decydentom, jakie są ich opinie, jak postrzegają pewne kwestie, czego oczekują. Konsultacje stanowią również formę współzarządzania jednostką samorządu i współodpowiedzialności za podejmowane decyzje. Mieszkańcy mają szansę współuczestniczyć w podejmowaniu decyzji dla dobra całej wspólnoty. Realnie wpływać na podejmowane decyzje, ale przede wszystkim decydować we współpracy z innymi o jakości swojego życia. 
Celem artykułu jest analiza formalnoprawnych uregulowań dotyczących konsultacji społecznych oraz ukazanie różnorodności rozwiązań stosowanych przez wybrane gminy - ze szczególnym uwzględnieniem sytuacji, w których uchwałodawca nie uwzględnia postulatów mieszkańców bądź stosuje uregulowania „antypartycypacyjne” - tzn. nie uwzględnia mieszkańców jako wnioskodawców, stawia ogromny próg zaporowy w postaci dużej liczby podpisów, nie stosuje zróżnicowanych technik konsultacyjnych, nie pozwala bądź nie określa możliwości złożenia protestu. Analizą objęte zostaną wybrane akty prawa miejscowego normujące konsultacje społeczne (zarówno większych ośrodków, jak: Poznań, Toruń, Warszawa, jak i małych gmin wiejskich). Ze względu na ramy niniejszego opracowania nie wszystkie aspekty zostaną dokładnie scharakteryzowane, a jedynie zasygnalizowane. Literatura dotycząca konsultacji jest bardzo boga$\mathrm{ta}^{1}$, jednakże głównym celem artykułu jest ukazanie konkretnych rozwiązań $\mathrm{w}$ formie uchwał, stąd też podstawowym źródłem są akty prawa miejscowego.

Obecnie konsultacje społeczne unormowane są na poziomie ustaw, jednak w konstytucji z 1997 roku znajdziemy wiele zasad ustrojowych odwołujących się do mechanizmu konsultacji społecznych oraz szczegółowych norm, które wprost udzielają społeczeństwu legitymacji do udziału w procesach decyzyjnych - począwszy od zasady demokratycznego państwa prawnego, poprzez zasady wyrażone już w preambule konstytucji: dialogu społecznego, subsydiarności, zaufania obywateli do państwa. Poza zasadami ustrojowymi w konstytucji znajduje się wiele przepisów, które określają współudział obywateli w kształtowaniu lokalnych polityk publicznych.

Jak już wspomniałam, w polskim systemie prawnym konsultacje społeczne uregulowane zostały szczegółowo na poziomie ustaw. Jednakże są to przepisy bardzo ogólne, ustawodawca w gestii władz samorządowych pozostawił ich uszczegółowienie na poziomie uchwał. Stąd też swoistego rodzaju „dowolność” i mnogość rozwiązań, które nie zawsze przystają do budowania partycypacyjnej wspólnoty lokalnej, zaangażowanej w rozwiązywanie lokalnych problemów i współrealizującej lokalne polityki publiczne. Ustawa o samorządzie gminnym w art. 5 ust. 1 stanowi, że: „W wypadkach przewidzianych ustawą oraz $\mathrm{w}$ innych sprawach ważnych dla gminy mogą być przeprowadzane na jej terytorium konsultacje z mieszkańcami gminy. Ust. 2. Zasady i tryb przeprowadzania konsultacji z mieszkańcami gminy określa uchwała rady gminy”. W ustawie o samorządzie powiatowym $\mathrm{w}$ art. $3 \mathrm{~d}$ oraz $\mathrm{w}$ ustawie o samorządzie wojewódzkim w art. 10a znajdziemy identyczne rozwiązanie formalnoprawne ${ }^{2}$. Konsultacje bez względu na szczebel samorządu mają charakter obligatoryjny lub fakultatywny. Ustawa o samorządzie gminnym przewiduje konsultacje obligatoryjne w zakresie:

1 Zob. Partycypacja społeczna w samorządzie terytorialnym, red. B. Dolnicki, Warszawa 2014; A. Ferens et al., Jak prowadzić konsultacje społeczne w samorzadach? Zasady i najlepsze praktyki wspótpracy samorzadów z przedstawicielami społeczności lokalnych. Przewodnik dla samorządów, Warszawa 2010; R. Marchaj, Samorzadowe konsultacje społeczne, Warszawa 2016; Prawo a partycypacja publiczna. Bilans monitoringu 2012, red. P. Sobiesiak-Penszko, Warszawa 2013.

${ }^{2}$ Ustawa z dnia 8 marca 1990 r. o samorządzie gminnym (Dz.U. Nr 16, poz. 95 z późn. zm.), ustawa z dnia 5 czerwca 1998 r. o samorządzie powiatowym (Dz.U. Nr 91, poz. 578 z późn. zm.) oraz ustawa z dnia 5 czerwca 1998 r. o samorządzie województwa (Dz.U. Nr 91, poz. 576 z późn. zm.). 
- tworzenia, łączenia, podziału i znoszenia gmin oraz ustalania ich granic;

- nadawania gminie lub miejscowości statusu miasta i ustalania jego granic;

- ustalania i zmieniania nazwy gmin oraz siedziby ich władz;

- tworzenia jednostki pomocniczej.

Ustawa o samorządzie powiatowym przewiduje konsultacje obligatoryjne w zakresie:

- tworzenia, łączenia, podziału i znoszenia powiatów oraz ustalania ich granic;

- ustalania i zmieniania nazwy powiatów oraz siedzib ich władz.

Ustawa o samorządzie województwa nie stanowi o takich przypadkach.

Poza obligatoryjnymi konsultacjami, wymienionymi powyżej, w polskim systemie prawnym znajdziemy wiele uregulowań, z których wynika obowiązek przeprowadzenia konsultacji przed podjęciem ważnych dla mieszkańców decyzji. Zaliczymy do nich m.in.: ustawę z dnia 27 kwietnia 2001 r. Prawo ochrony środowiska (Dz.U. z 2001 r. Nr 62, poz. 627 z późn. zm.) oraz ustawę z dnia 27 marca 2003 r. o planowaniu i zagospodarowaniu przestrzennym (Dz.U. z 2003 r. Nr 80, poz. 717 z późn. zm.). Pamiętajmy, iż obligatoryjne konsultacje to uprawnienie mieszkańców, a dla władz jednostek samorządowych to obowiązek działania zgodnie z prawem. Niezachowanie wymogu przeprowadzenia konsultacji społecznych będzie miało poważne konsekwencje w sferze ważności podjętych decyzji lub działań i będzie rażącym naruszeniem norm prawnych i standardów. Jednakże wyniki konsultacji nie są wiążące dla władz lokalnych — mogą, ale nie muszą zostać uwzględnione przy podejmowaniu decyzji.

\section{Uchwały w sprawach konsultacji społecznych - różnorodność rozwiązań}

W polskim prawie brakuje legalnej definicji konsultacji społecznych. Należy więc posłużyć się wykładnią słownikową. Konsultacja jest terminem pochodzącym z języka łacińskiego (consulto oznacza „radzić się”). Według Słownika języka polskiego jest to porada, udzielenie wskazówek, zasięganie opinii, najczęściej u fachowców, specjalistów z jakiejś dziedziny. Szukając odpowiedzi na pytanie, jak najrzetelniej zdefiniować konsultacje, warto przywołać dwie pozycje charakteryzujące konsultacje całościowo, szczególnie akcentujące kwestie standardów: Konsultacje społeczne - jak sprawić by były lepsze? Propozycja Kodeksu Konsultacji i ścieżka wdrożenia wraz z siedmioma zasadami konsultacji społecznych, opracowane przez ekspertów społecznych i przedstawicieli administracji pod auspicjami Ministerstwa Administracji i Cyfryzacji w 2012 roku oraz Kanon Lokalnych Konsultacji Społecznych - rezultat prac grupy roboczej, w której skład weszli przedstawiciele środowisk społecznych i rządowych. Kanon został opracowany w ramach projektu Decydujmy Razem opublikowanego w czerwcu 2014 roku przez Fundację Inicjatyw Społeczno-Ekonomicznych. W świetle Kodeksu Konsultacji: „Konsultacje są kluczowym sposobem włączania obywateli w proces podejmowania decyzji. Udział obywateli w procesie kształtowania polityk publicznych i rozwiązań prawnych przyczynia się do urzeczywistniania dobra wspólnego postrzeganego w kategorii jakości życia 
całej społeczności” ${ }^{3}$ Z k kolei w Kanonie Konsultacji możemy przeczytać: „Konsultacje stanowią jedną $\mathrm{z}$ form udziału obywateli w sprawowaniu władzy, co jest umocowane w przepisach Konstytucji i odpowiednich ustaw"4.

Ustawodawca nie określił również definicji ustawowej terminu „sprawa ważna”, dlatego mogą pojawiać się, i oczywiście pojawiają, wątpliwości interpretacyjne. Wydaje się, iż powinno być to określenie zbiorcze wszystkich zadań mieszczących się w kompetencjach poszczególnych szczebli samorządu terytorialnego. Uchwały w różnorodny sposób definiują bądź nie definiują „spraw ważnych” - począwszy od stworzenia swoistego rodzaju listy, jak zrobiono to w Katowicach, w Uchwale Nr XXXVIII/860/13 z dnia 26 czerwca $2013 \mathrm{r}$. w sprawie zasad i trybów przeprowadzania konsultacji z mieszkańcami miasta Katowice w $\$ 1$ przewiduje się, przeprowadzanie konsultacji w przypadkach przewidzianych ustawą lub w innych sprawach ważnych dla miasta. Natomiast $\$ 4$ określa, że konsultacje z mieszkańcami miasta Katowice mogą być przeprowadzone w sprawach dotyczących w szczególności: strategii rozwoju miasta, wieloletnich planów inwestycyjnych, inwestycji miasta, organizacji komunikacji miejskiej, systemu gospodarki odpadami miasta, strategii rozwiązywania problemów społecznych miasta, strategii i programów branżowych $\mathrm{w}$ dziedzinach obejmujących zadania własne miasta, budżetu miasta wraz z Wieloletnią Prognozą Finansową. Znajdziemy też takie rozwiązania, jak w powiecie zgorzeleckim, gdy konsultacje (poza obligatoryjnymi) przeprowadza się w sprawach ważnych dla samorządu powiatu przy opracowywaniu takich dokumentów jak: Strategia Rozwoju Powiatu Zgorzeleckiego, Plan Rozwoju Lokalnego Powiatu Zgorzeleckiego $(\$ 1)^{5}$. Powstaje jednak pytanie, czy mają to być sprawy ważne dla samorządu powiatu rozumianego jako mieszkańcy, czy też dla samorządu w rozumieniu władz powiatowych? Może się okazać, że nie zawsze obie strony mają na względzie identyczne kwestie. Oczywiście, uchwały w sprawie przeprowadzania konsultacji nie dają nam odpowiedzi na ten temat.

Sporadycznie zdarza się, iż władze decydują się na wprowadzenie preambuły. Tak postanowiono w Krakowie, określając, że: „zdecydowano się na prowadzenie konsultacji społecznych na podstawie uchwały w trosce o rozwój społeczeństwa i wdrażanie idei wspólnoty samorządowej” 6 .Z kolei w katowickiej uchwale w $\$ 1$ pkt 2 i 3 szczegółowo określono cel konsultacji jako: „włączanie społeczeństwa w proces podejmowania decyzji, zaś analiza zebranych $\mathrm{w}$ ramach konsultacji opinii i uwag ma służyć optymalnemu dobraniu skali, zakresu oraz charakteru działań miasta pod kątem zaspokajania potrzeb i oczekiwań społecznych oraz inicjowania działań władz miasta. Włączanie mieszkańców do proce-

${ }^{3}$ Konsultacje społeczne - jak sprawić by byty lepsze? Propozycja Kodeksu Konsultacji i ścieżka wdrożenia, MAiC 2012, s. 6, https://mac.gov.pl/files/konsultacje-spoleczne.pdf (dostęp: 14.07.2014).

${ }^{4}$ Kanon Lokalnych Konsultacji Społecznych, broszura pt. Regulamin konsultacji społecznych. Wytyczne, rekomendacje przykłady, Warszawa 2014, s. 3 lub http://kanonkonsultacji.pl/.

${ }^{5}$ Por. Uchwała nr LV/332/2006 Rady Powiatu Zgorzeleckiego z dnia 31 sierpnia 2006 r. w sprawie zasad i trybu przeprowadzania konsultacji z mieszkańcami powiatu zgorzeleckiego.

6 Załącznik do uchwały nr XLI/502/08 Rady Miasta Krakowa z dnia 23 kwietnia 2008 r. w sprawie zasad i trybu przeprowadzania konsultacji z mieszkańcami gminy miejskiej Kraków przy realizacji inwestycji i projektów miejskich. 
sów decyzyjnych ma odbywać się na zasadzie wzajemnej, dwukierunkowej komunikacji potrzeb oraz oczekiwań, z wykorzystaniem narzędzi dialogu społecznego" ${ }^{\prime 7}$. Określenie celu konsultacji oraz wskazanie ważności/istotności zagadnień powinno być dobrym obyczajem w formułowaniu tekstów uchwał. Niekiedy spotykamy się ze stwierdzeniem, iż konsultacje przeprowadza się: „w celu pozyskania społecznego zrozumienia dla projektowanych rozwiązań”8. Wydaje się, że konsultacje co prawda mogą mieć na celu przekonanie części mieszkańców sceptycznie nastawionych do proponowanych rozwiązań, jednakże takie stwierdzenie nie powinno mieć miejsca w akcie prawa miejscowego. Pokazuje ono całkowite niezrozumienie przez lokalne władze istoty konsultacji społecznych.

Zasady i tryb przeprowadzania konsultacji określa rada gminy w uchwale. W praktyce funkcjonowania polskiego samorządu spora część jednostek ma już stosowne akty, z zastrzeżeniem, że są to uchwały różnej jakości (o różnym stopniu szczegółowości i różnorodnych rozwiązaniach). Wśród rozwiązań stosowanych przez lokalne władze, normujących konsultacje, można wymienić: uchwały dotyczące różnego rodzaju konsultacji społecznych (czasami uszczegółowione o akty wykonawcze/zarządzenia/regulaminy) unormowania zawarte w statutach (większość unormowań statutowych dotyczy przeprowadzania obligatoryjnych konsultacji wynikających $\mathrm{z}$ art. 4a ustawy o samorządzie gminnym, można też podać bardzo nieliczne przykłady, jak chociażby Bielsk Podlaski, który w swoim statucie poza unormowaniem obligatoryjnych konsultacji odnosi się także do kwestii konsultacji fakultatywnych przeprowadzanych w różnych sprawach ${ }^{10}$ ), uchwały $\mathrm{w}$ sprawie konsultacji społecznych $\mathrm{z}$ udziałem organizacji pozarządowych ${ }^{11}$ oraz uchwały w sprawie konsultacji społecznych konkretnej procedury w szczególnej, określonej kwestii ${ }^{12}$.

7 Uchwała nr XXXVIII/860/13 Rady Miasta Katowice z dnia 26 czerwca 2013 r. w sprawie zasad i trybów przeprowadzania konsultacji z mieszkańcami miasta Katowice.

8 Przykładowo: Uchwała nr 848/L/2014 Rady Miasta Płocka z dnia 26 sierpnia 2014 r. w sprawie zasad i trybu przeprowadzania konsultacji społecznych na terenie miasta Płocka; Uchwała nr VIII/88/15 Rady Miejskiej w Pabianicach z dnia 26 marca 2015 r. w sprawie zasad i trybu przeprowadzania konsultacji z mieszkańcami Miasta Pabianic oraz z organizacjami pozarządowymi i podmiotami wymienionymi $\mathrm{w}$ art. 3 ust. 3 ustawy z dnia 24 kwietnia 2003 r. o działalności pożytku publicznego i o wolontariacie.

9 Przykładowo m.st. Warszawa ma Uchwałę nr LXI/1691/2013 Rady Miasta Stołecznego Warszawy z dnia 11 lipca 2013 r. w sprawie zasad i trybu przeprowadzania konsultacji z mieszkańcami m.st. Warszawy. Do uchwały został wydany akt wykonawczy w postaci Zarządzenia nr 4925/2013 Prezydenta Miasta Stołecznego Warszawy z dnia 3 września 2013 r. w sprawie określenia postępowania w Urzędzie m.st. Warszawy w związku z przeprowadzanymi konsultacjami z mieszkańcami m.st. Warszawy.

$10 \mathrm{~W}$ art. 7 pkt 2 Statut miasta Bielsk Podlaski zawiera możliwość przeprowadzenia konsultacji z mieszkańcami miasta w każdej ważnej sprawie. Zob. A. Maszkowska, M. Wenclik, Partycypacja publiczna w województwie podlaskim - raport z badań, Białystok 2015, s. 13-14.

11 Np. Uchwała nr 360/2013 Rady Miasta Zgorzelec z dnia 29 października 2013 r. w sprawie przyjęcia programu współpracy Gminy Miejskiej Zgorzelec z organizacjami pozarządowymi oraz innymi podmiotami prowadzącymi działalność pożytku publicznego w roku 2014.

12 Uchwała nr XVIII/366/15 Rady Miejskiej Wrocławia z dnia 26 listopada 2015 r. w sprawie konsultacji projektu uchwały zmieniającej uchwały w sprawie nadania statutów osiedli; Uchwała nr VII/64/2015 Rady Miasta Sopotu z dnia 27 kwietnia 2015 r. w sprawie przeprowadzenia konsultacji społecznych z mieszkańcami Sopotu dotyczących Sopockiego Programu Strategicznego na rzecz Seniorów do 2020. 
W większości przypadków konsultacje społeczne unormowane są w odrębnych uchwałach dotyczących różnego rodzaju konsultacji (część gmin, szczególnie dużych jednostek, ma także akty wykonawcze w postaci zarządzeń czy regulaminów, np. Warszawa, Katowice ${ }^{13}$ czy Toruń $\left.{ }^{14}\right)$. Zdarzają się sytuacje, jak w gminie Bielsk, gdy władze gminy, nie stosując się do rozwiązań ustawowych, próbują przeprowadzać konsultacje np. na podstawie zarządzeń wójta. Wójt gminy Bielsk 5 sierpnia 2014 roku wydał zarządzenie $\mathrm{w}$ sprawie przeprowadzenia konsultacji społecznych z mieszkańcami w sprawie nadania nazwy dla placu (skweru). Rozstrzygnięciem nadzorczym wojewoda mazowiecki stwierdził nieważność przedmiotowego zarządzenia ${ }^{15}$.

$\mathrm{Z}$ wnioskiem o przeprowadzenie konsultacji mogą występować różnorodne podmioty. W wielu sytuacjach prawo takie przysługuje mieszkańcom, np. w Katowicach w liczbie co najmniej 100, w Warszawie w liczbie co najmniej 1000, lecz mającym czynne prawo wyborcze do Rady Miasta Stołecznego Warszawy, a w Krakowie w liczbie co najmniej 2000 - również wtedy, gdy mają czynne prawo wyborcze ${ }^{16}$. Z kolei w Toruniu liczbę tę określono na 150 mieszkańców. Co ciekawe, w znacznie większej niż Kraków Warszawie wymagana jest mniejsza o połowę liczba podpisów pod wnioskiem. W 2014 roku Katowice liczyły 301834 mieszkańców ${ }^{17}$, Toruń zaś - 203158 osób ${ }^{18}$. Można odnieść wrażenie, iż władze, tworząc akty prawa miejscowego, całkowicie przypadkiem (bezrefleksyjnie) określają liczbę wnioskodawców lub też wprowadzając rygorystyczne progi, dążą do zmarginalizowania i utrudnienia $\mathrm{w}$ dostępie do tego narzędzia partycypacji.

Uchwała nr XI/143/2007 Rady Miasta Sopotu z dnia 30 listopada 2007 roku w sprawie zasad i trybu przeprowadzania konsultacji z mieszkańcami Sopotu ${ }^{19}$ nie przewidziała wcale możliwości złożenia wniosku przez mieszkańców miasta, pozostawiając to szczególnie istotne uprawnienie w gestii prezydenta miasta oraz przewodniczącego

13 Uchwała nr XXXVIII/860/13 Rady Miasta Katowice...

14 Uchwała nr 508/2013 Rady Miasta Torunia z dnia 21 lutego 2013 r. w sprawie Regulaminu Konsultacji Społecznych.

15 Zob. Rozstrzygnięcie nadzorcze Wojewody Mazowieckiego z dnia 30 września 2014 r. stwierdzające nieważność zarządzenia Wójta Gminy Bielsk nr 34/2014 z dnia 5 sierpnia 2014 r. w sprawie przeprowadzenia konsultacji społecznych dotyczących nadania nazwy dla placu/skweru położonego w części działki nr 599 w Bielsku (LEX.P.4131.34.2014.PM).

16 Uchwała nr XLI/502/08 Rady Miasta Krakowa...

$17 \mathrm{http} / /$ katowice.stat.gov.pl/vademecum/vademecum_slaskie/portrety_miast/miasto_katowice.pdf (dostęp: 4.01.2016).

$18 \mathrm{http}: / /$ bydgoszcz.stat.gov.pl/vademecum/vademecum_kujawskopomorskie/portrety_miast/miasto_ torun.pdf (dostęp: 4.01.2016).

19 Z Sopotem wiąże się jeszcze jedna interesująca sprawa ukazująca bierność i opór władz z jednej strony, a z drugiej inicjatywę mieszkańców, którzy niestety są przez władze ignorowani. W 2010 roku Sopocka Inicjatywa Rozwojowa (nieformalna grupa mieszkańców Sopotu) wystąiła do władz miasta z obywatelskim projektem uchwały w sprawie konsultacji społecznych. Projekt zawierał wiele rozwiązań proobywatelskich, czyniąc konsultacje społeczne otwartymi, przyjaznymi i przeprowadzanymi w duchu partycypacyjnym. Niestety władze miasta nie pochyliły się nad propozycjami obywateli (po kilku latach projekt został odrzucony przez radnych). W roku 2015 Sopocka Inicjatywa Rozwojowa, ulepszając projekt, postanowiła złożyć go jeszcze raz - jako obywatelski projekt uchwały. Zob. http://www.sopockainicjatywa.org/2015/07/28/ czas-na-nowy-regulamin-konsultacji-spolecznych-w-sopocie/\#more-22340 (dostęp: 12.12.2015). 
rady miasta. Zgodnie $\mathrm{z}$ wieloma regulacjami w uchwałach możliwość złożenia wniosku posiadają przeważnie wójtowie, burmistrzowie, prezydenci, radni bądź ich grupy, organizacje pozarządowe (czasami w liczbie np. 5, jak w Toruniu, bądź 40 jak w Warszawie), młodzieżowe rady miasta, Rady Działalności Pożytku Publicznego.

Główny podmiot, dla którego przeprowadza się konsultacje i który jest odbiorcą oraz powinien być współdecydentem i współodpowiedzialnym za podejmowane decyzje, albo zostaje pominięty, jak w Sopocie, albo wymaga się od niego danych szczegółowych przy składaniu wniosku (PESEL), albo obwarowuje się uprawnienia mieszkańców dodatkowymi obostrzeniami w postaci posiadania czynnego prawa wyborczego. Może się oczywiście zdarzyć, że osoba niemająca czynnego prawa wyborczego jest mieszkańcem i też powinna mieć możliwość składania wniosków w celu realizacji konsultacji społecznych (potwierdzenie tej tezy znajduje swoje odzwierciedlenie w orzecznictwie sądów administracyjnych) ${ }^{20}$. Również wymogi dotyczące numeru PESEL zostały uznane przez judykaturę za wykraczające poza granice przyznanych przez ustawodawcę kompetencji wynikających z ustawy o samorządzie gminnym ${ }^{21}$. Kolejną kwestią jest wymóg zameldowania nieprzystający całkowicie do dzisiejszych realiów, lecz także niezgodny z dyspozycją ustawową zawartą $\mathrm{w}$ ustawie o samorządzie gminnym w art. 5a, gdyż mowa jest tam jedynie o mieszkańcach, stąd też zawężanie tego przepisu do osób mających zameldowanie jest naruszeniem prawa. Mieszkańcy bardzo często wynajmują mieszkania (szczególnie w dużych miastach), nie będąc zameldowanymi, co uniemożliwia im skorzystanie z uprawnień na obszarze, na którym mieszkają, czasami od wielu lat, pracują, wychowują dzieci, są związani długoletnią więzią gospodarczą oraz społeczną. Poza tym $w$ wielu uchwałach znajdujemy ograniczenie wiekowe (stosuje się wymóg pełnoletniości przy jednoczesnym określeniu, że podmiotem, który może złożyć wniosek, jest młodzieżowa rada gminy/miasta, w której z oczywistych względów zasiadają również osoby niepełnoletnie).

Podmiotem uprawnionym do uczestniczenia w konsultacjach są mieszkańcy gminy, co wynika wprost $z$ ustawy o samorządzie gminnym (ustawodawca nie sformułował żadnych innych przesłanek w postaci czynnego prawa wyborczego, pełnoletności czy też posiadania zameldowania). Czasami w uchwałach zawarty zostaje przepis mówiący o pełnoletnich mieszkańcach gminy. Stoi to w sprzeczności zarówno z art. 5a ustawy o samorządzie gminnym, jak i z orzecznictwem sądów, a dodatkowo z logiką, gdyż niepełnoletni mieszkańcy gminy też mogą być zainteresowani udziałem w konsultacjach w niektórych sprawach. Z reguły organy nadzoru dokonują eliminacji takich rozwiązań,

20 Zob. Wyrok WSA we Wrocławiu z dnia 29 kwietnia 2011r., III SA/Wr 20/11 http://orzeczenia.nsa. gov.pl/doc/1B6B341F35 (dostęp: 13.12.2015).

${ }^{21}$ Zob. Wyrok WSA we Wrocławiu z dnia 10 maja 2013 r., III SA/Wr 140/13. Stwierdzono, że wprowadzenie takiego unormowania jest nie tylko nieuprawnionym tworzeniem przez organ stanowiący dodatkowych, nieprzewidzianych ustawowo kryteriów niesłużących przecież określeniu mieszkańca gminy, lecz stanowi także ograniczenie kręgu mieszkańców gminy do osób legitymujących się numerem PESEL, a więc pomija przypadki, w których mieszkaniec gminy nie dysponuje takim kodem. Tymczasem z ustawowego upoważnienia do uchwalenia zasad i trybu przeprowadzenia konsultacji z mieszkańcami gminy nie można wyprowadzić kompetencji rady gminy do ograniczenia kręgu osób uprawnionych do udziału w konsultacjach społecznych, http://orzeczenia.nsa.gov.pl/doc/23C25CAA22 (dostęp: 17.12.2015). 
tak jak w gminie Grzmiąca czy w gminie Pawłowiczki ${ }^{22}$. Od czasu do czasu ustawodawcy postanawiają, że uczestnikiem konsultacji mogą być jedynie osoby zameldowane na terenie danej gminy. Jest to również niezgodne z prawem oraz logiką (o czym piszę wyżej w odniesieniu do katalogu wnioskodawców w sprawie przeprowadzania konsultacji). Takie rozwiązanie zaproponowano w uchwale miasta Darłowo, jednakże wojewoda zachodniopomorski rozstrzygnięciem nadzorczym usunął ten przepis ${ }^{23}$ (również w Strzelcach Krajeńskich organ nadzoru wyeliminował przepis) ${ }^{24}$. Identycznie sytuacja wygląda odnośnie do przesłanki mówiącej o czynnym prawie wyborczym jako elemencie niezbędnym do uczestniczenia w konsultacjach.

Władze niektórych samorządów decydują się na utworzenie specjalnych organów opiniodawczo-doradczych do spraw konsultacji społecznych, których zadaniem bywa wypracowanie standardów, opiniowanie odbytych konsultacji bądź proponowanie nowych rozwiązań. Są to organy, których refleksja nad tym, jak przeprowadzamy konsultacje, ma na celu ulepszenie całego procesu. Ciało takie zostało powołane w Toruniu, jako Rada Społeczna ds. Konsultacji Społecznych, której członków powołuje Prezydent spośród radnych wskazanych przez Radę ( 3 osoby), kandydatów zgłoszonych przez organizacje pozarządowe działające na terenie miasta ( 3 osoby) oraz kandydatów zgłoszonych przez mieszkańców (3 osoby) i 3 pracowników Urzędu Miasta Torunia. Do zadań Rady Społecznej należy: opracowanie w terminie 9 miesięcy od powołania powszechnie akceptowanych i skutecznych metod oraz form przeprowadzania konsultacji (Dobre Praktyki Prowadzenia Konsultacji), ich aktualizacja oraz przedstawianie Radzie do 30 marca każdego roku rocznego sprawozdania z przeprowadzonych konsultacji, wraz z wnioska$\mathrm{mi}^{25}$. Z kolei na mocy krakowskiej uchwały utworzono Komitet Sterujący ds. Konsultacji Społecznych, powoływany przez prezydenta. Jednakże poza rekomendacjami, które ma on wydawać w sprawach tzw. ofert kompensacyjnych, brakuje jakichkolwiek uregulowań tego organu ${ }^{26}$. Inicjatywa godna pochwały. Miejmy nadzieję, iż organ ten nie będzie

22 Por. Rozstrzygnięcie nadzorcze nr NK.4.4131.166.2013 Wojewody Zachodniopomorskiego z dnia 6 marca 2013 r. stwierdzające nieważność $\$ 3$ załącznika do uchwały Nr XXV/146/2013 Rady Gminy Grzmiąca z dnia 30 stycznia 2013 r. w sprawie określenia zasad i trybu konsultacji społecznych z mieszkańcami Gminy Grzmiąca (Dz.Urz. Woj. Zachodniopomorskiego, poz. 1246) oraz Rozstrzygnięcie nadzorcze nr NK.III.4131.1.16.2013 Wojewody Opolskiego z dnia 28 lutego 2013 r. w sprawie stwierdzenia nieważności części uchwały nr XXIII/139/13 Rady Gminy Pawłowiczki z dnia 24 stycznia 2013 r. w sprawie określenia zasad i trybu przeprowadzania konsultacji społecznych z mieszkańcami gminy Pawłowiczki (Dz.Urz. Woj. Opolskiego, poz. 607).

23 Zob. Rozstrzygnięcie nadzorcze nr NK.4.MN.0911-102/2007 Wojewody Zachodniopomorskiego z dnia 6 lipca 2007 r. stwierdzające nieważność $\$ 1$ ust. 4 uchwały nr VIII/84/07 Rady Miejskiej w Darłowie z dnia 19 czerwca 2007 r. w sprawie zasad i trybu przeprowadzania konsultacji z mieszkańcami miasta Darłowo.

24 Zob. Rozstrzygnięcie nadzorcze nr NK-I.4131.65.2015.I Wojewody Lubuskiego z dnia 24 kwietnia 2015 r. stwierdzające nieważność części uchwały nr VI/31/15 Rady miejskiej w Strzelcach Krajeńskich z dnia 27 marca 2015 r. w sprawie przeprowadzenia na terenie gminy Strzelce Krajeńskie konsultacji społecznych w sprawie Budżetu Obywatelskiego jako części budżetu Gminy na 2016 rok (Dz.Urz. Woj. Lubuskiego, poz. 832).

25 \$ 11-\$ 22 uchwały nr 508/2013 Rady Miasta Torunia...

$26 § 8$ pkt 3 załącznika do uchwały nr XLI/502/08 Rady Miasta Krakowa... 
bezwolnym wykonawcą woli władz samorządowych, lecz kreatywnym doradcą i surowym cenzorem wszystkich aspektów konsultacji społecznych.

Jednym z istotnych elementów uchwał powinny być zróżnicowane formy konsultacji. Zasięganie opinii za pomocą różnego typu narzędzi i technik pozwala na dogłębną analizę oraz realizację zakładanych celów konsultacji. Katalog form, jakie mamy do wyboru, jest bardzo rozbudowany, jednakże gminy, poza wyjątkami, boją się korzystać z innowacyjnych metod. Przyczyny tego stanu zapewne są różnorakie - począwszy od generowania dodatkowych kosztów, poprzez nieumiejętność stosowania, aż po niechęć do innowacji i stosowanie tzw. starych, lecz wypróbowanych metod, które w rezultacie mogą nie przynosić zamierzonego efektu. Im większa i zasobniejsza $\mathrm{w}$ fundusze gmina czy powiat, tym katalog form konsultacji jest bardziej rozbudowany, co oczywiście jest zrozumiałe, lecz nawet $\mathrm{w}$ dużych aglomeracjach nie wykorzystuje się wielu technik. Do wyboru mamy wiele różnych form aktywizujących obywateli, pozwalających im na zabranie głosu i wyrażenie swojej opinii - od najprostszych ankiet przesyłanych do urzędu (elektronicznie lub w formie tradycyjnej) poprzez spotkania otwarte - publiczne, które wymagają przygotowania i organizacji aż po panele ekspertów, które również należy przygotować oraz liczyć się z ewentualnymi kosztami za dokonanych ekspertyz. Do wyboru mamy także spotkania „na żywo", w internecie, wywiady indywidualne za pomocą kwestionariuszy, badania na próbce reprezentatywnej, karty rozmowy, grupy fokusowe, sondaże deliberatywne, koła przypadków, referenda lokalne czy też sąd obywatelski ${ }^{27}$. Wśród rozwiązań pojawiających się w uchwałach znajdziemy (uchwała toruńska): sondaż lub ankietę ilościową, opinie i uwagi zebrane w zwyczajowy sposób, w tym także drogą elektroniczną, otwarte spotkania (debaty) lub inne podobne formy, różne warsztaty obywatelskie, takie jak np. grupa reprezentatywna, zespoły planujące, a także inne inicjatywy. Dodatkową formą konsultacji, która może zostać uwzględniona w procesie konsultacji, jest zespół ekspercki powoływany każdorazowo przez prezydenta. W uchwale warszawskiej również mamy do wyboru wiele form w postaci: protokołowanych otwartych spotkań z mieszkańcami, pisemnego, w tym elektronicznego, zbierania uwag, zbierania uwag w punkcie konsultacyjnym, warsztatów projektowych będących ustrukturyzowaną pracą grupy osób, prowadzącą do wypracowania propozycji rozwiązań, ankiet samodzielnie wypełnianych przez respondentów, w szczególności wypełnianych przy użyciu internetu, paneli obywatelskich polegających na regularnym zasięganiu przez dłuższy okres opinii dużej, reprezentatywnej grupy mieszkańców). Natomiast $\mathrm{w}$ uchwale powiatu zgorzeleckiego mamy do czynienia jedynie $\mathrm{z}$ takimi formami, jak: debata $\mathrm{z}$ mieszkańcami, debata $\mathrm{z}$ organizacjami pozarządowymi, ankiety wrzucane do skrzynek, sonda internetowa, internetowe forum. Z kolei w małej, wiejskiej gminie Goszczyn określono, że mogą to być: otwarte spotkania z mieszkańcami, badanie opinii mieszkańców z wykorzystaniem formularza ankietowego ( $w$ tym ankie-

27 A. Ferens, P. Drzewiński, M. Olejnik, Aktywne narzędzia i techniki prowadzenia konsultacji, [w:] Narzędzia i techniki konsultacji społecznych. Podręcznik jak prowadzić konsultacje społeczne w samorządzie, Katowice 2013, s. 23-57. 
ty elektroniczne $)^{28}$. W uchwale gminy Świerklany w specyficzny sposób określono formy konsultacji jako: pisemne (w tym elektroniczne) - poprzez umieszczenie projektu aktu prawa miejscowego w Biuletynie Informacji Publicznej Urzędu Gminy Świerklany, bezpośrednie spotkania $\mathrm{z}$ mieszkańcami we wszystkich lub wybranych okręgach wyborczych, środowiskowe zebrania przedstawicieli organizacji politycznych, sportowych, społecznych i zawodowych działających na terenie Gminy Świerklany ${ }^{29}$. Niestety często zdarza się tak, jak w uchwale gminy Rewal, że konsultacje mogą być przeprowadzane w formie: wyrażenia opinii i złożenia uwag do sprawy będącej przedmiotem konsultacji, udzielenia odpowiedzi na postawione pytanie lub pytania, wyboru jednego z proponowanych rozwiązań ${ }^{30}$. Pomimo tego, że uchwała pochodzi z 2015 roku i mamy już w tym zakresie w praktyce jednostek samorządu terytorialnego wypracowane rozwiązania, nie skorzystano z nich. Wśród stosowanych rozwiązań często pojawia się zapis, że konsultacje można przeprowadzić $w$ innej formie, jeżeli będzie to konieczne. $Z$ reguły decyzję w przedmiotowej kwestii podejmuje organ wykonawczy. Jednym z ciekawszych rozwiązań są platformy konsultacji społecznych, czyli strony internetowe prowadzone przez urzędy, poświęcone jedynie tej tematyce. Platformy odnajdziemy w Warszawie, Katowicach, Olsztynie, Poznaniu, Wrocławiu, Giżycku czy Pleśnej. Jest to tani, nowoczesny i skuteczny sposób na rozpowszechnianie informacji, zbieranie opinii oraz prowadzenie przez urzędy dialogu z mieszkańcami. Ponadto jest to miejsce, w którym istnieje możliwość zaprezentowania dokumentów, zdjęć, filmów, formularzy do pobrania czy też „czatów na żywo". Pamiętajmy jednak, że nie powinna być to jedyna droga komunikacji z mieszkańcami, gdyż część z nich (szczególnie starszych) nie korzysta codziennie z internetu, nie porusza się sprawnie i swobodnie w tym „gąszczu” informacji. Nie zawsze będą one w stanie dojrzeć i znaleźć potrzebne informacje. Nic nie zastąpi bezpośredniej rozmowy — gdy wszystkie strony są aktywne i próbują się z sobą porozumieć, spierają się, dyskutują, przedstawiając swoje racje. Z pewnością spora część jednostek samorządu nie korzysta $z$ innowacyjnych form prowadzenia konsultacji społecznych, a przyczyn tego stanu rzeczy należy upatrywać z jednej strony w oszczędnościach, a z drugiej $\mathrm{w}$ obawach przed stosowaniem nowych, nieznanych formul. Zdarzają się też takie samorządy, które wdrażają nowoczesne techniki - chociażby najbardziej znany w Polsce przypadek sądu obywatelskiego w Poznaniu, dotyczącego ulicy Umultowskiej. Zresztą to niejedyne innowacyjne formy, które zastosowano w Poznaniu. Konsultując zagospodarowanie terenu w rejonie stadionu im. Szyca, skorzystano z sondażu deliberatywnego ${ }^{31}$.

28 Uchwała nr V/27/2011 Rady Gminy Goszczyn z dnia 29 marca 2011 r. w sprawie określenia zasad i trybu przeprowadzania konsultacji społecznych.

${ }^{29}$ Uchwała nr 56/VIII/15 Rady Gminy Świerklany z dnia 3 lipca 2015 r. w sprawie zasad i trybu przeprowadzania konsultacji z mieszkańcami Gminy Świerklany.

30 Uchwała nr IX/22/15 Rady Gminy Rewal z dnia 6 marca 2015 r. w sprawie zasad i trybu przeprowadzania konsultacji społecznych z mieszkańcami gminy Rewal.

31 Władze Poznania 13 grudnia 2013 r. zdecydowały się na zastosowanie techniki konsultacyjnej zwanej sądem obywatelskim w sprawie fragmentu ul. Umultowskiej, która biegnie wśród osiedla "Różany Potok” i jednocześnie sąsiaduje z cennym przyrodniczo obszarem pn. „Stawy Umultowskie”, który jest miejscem wypoczynku i rekreacji wielu poznaniaków. Ponieważ społeczeństwo lokalne było podzielone: jedni chcie- 
Poza standardami prawnymi wynikającymi z przepisów prawa niezwykle istotne jest dostrzeganie i przede wszystkim przestrzeganie standardów pozaprawnych będących powszechnie akceptowanymi zasadami współdziałania, współpracy i rozmowy o sprawach najważniejszych dla społeczności lokalnych. Standardy pozaprawne to etyczne reguły oraz zasady etykiety, wzajemny szacunek i uczciwość. Są one uznaniem obydwu stron za równorzędnych partnerów $\mathrm{w}$ trakcie debaty. Jednakże ramy niniejszego opracowania nie pozwalają na szczegółowe omówienie tych kwestii.

Wiele gmin stosuje rozwiązania dotyczące ważności konsultacji bez względu na frekwencję. Zdarzają się jednak wyjątki. W uchwale Rady Powiatu Brzeskiego postanowiono, że konsultacje są ważne, jeśli wypowie się w nich co najmniej $30 \%$ mieszkańców uprawnionych do głosowania ${ }^{32}$. Regułą jest również niezwiązanie organu gminy rozstrzygnięciem, które zapadło w efekcie konsultacji. Jednakże istotne z punktu widzenia mechanizmów partycypacji jest określenie (jak to zrobiono w uchwale toruńskiej), że pomimo niewiążącego charakteru konsultacji stanowią one istotną opinię przy podejmowaniu rozstrzygnięć $\mathrm{w}$ sprawach dotyczących przedmiotu konsultacji. Takie podejście, pod warunkiem, że będzie wdrażane, oznacza poważne traktowanie głosu mieszkańców wspólnoty lokalnej, liczenie się z ich zdaniem i włączanie ich we współzarządzanie sprawami lokalnymi. W podobny sposób rozwiązano to w Myszkowie, stanowiąc, że wynik konsultacji jest zawsze brany od uwagę, lecz nie jest wiążący dla organów miasta Myszkowa podejmujących rozstrzygnięcia w sprawach objętych konsultacjami ${ }^{33}$. Uchwały w sprawach konsultacji z mieszkańcami zawierają wiele innych, równie ważnych rozwiązań, które mogą być przedmiotem rozważań w odrębnych opracowaniach. Nie mniej istotne jest zawarcie w nich możliwości wniesienia odwołań bądź protestów. Zdarza się to sporadycznie. Elementami koniecznymi są informowanie, raportowanie nie tylko o wynikach konsultacji, lecz o całym ich przebiegu. Ostatnim ogniwem procesu konsultacyjnego powinna być rzetelnie przeprowadzona ewaluacja jego organizacji oraz jakości.

li jej przejezdności, inni byli za całkowitym zamknięciem i nadaniem jej charakteru pieszo-rowerowego ówczesny prezydent Poznania postanowił skorzystać z tej mało znanej w Polsce techniki konsultacyjnej i obiecał, że jej wyniki będą dla niego oraz dla Miejskiej Pracowni Urbanistycznej rekomendacjami. W wyniku przeprowadzonych konsultacji zapadł swoistego rodzaju „wyrok”, w którym określono, iż fragment Umultowskiej powinien zostać zamknięty. Zob. http://www.poznan.pl/mim/main/sad-obywatelski-w-sprawie-ul-umultowskiej,p,15574,21903.html (dostęp: 19.12.2015).

32 Por. Uchwała nr XL/397/2006 Rady Powiatu Brzeskiego z dnia 26 stycznia 2006 r. w sprawie zasad i trybu przeprowadzania konsultacji z mieszkańcami Powiatu Brzeskiego (Dz. Urz. Woj. Opolskiego Nr 18, poz. 648). Co ciekawsze, uchwałodawca nie określił, co w sytuacji nieważności konsultacji (tzn. gdy nie wypowie się $30 \%$ mieszkańców). Nie ustalił również, czy konsultacje są wiążące, czy wiążące nie są. Ponadto w uchwale tej znalazło się jeszcze jedno „ciekawe” rozwiązanie, a mianowicie Rada Powiatu, która rozpatruje wniosek o przeprowadzenie konsultacji, nie jest związana treścią wniosku, który wpłynął. Może wprowadzać zmiany lub żądać uzupełnienia wniosku. O ile to ostatnie jest zrozumiałe w przypadku braków formalnych lub jakichś oczywistych omyłek, o tyle samowolne wprowadzenie zmian bez zgody i może nawet wiedzy wnioskodawcy jest ingerencją w sedno sprawy i może spowodować wypaczenie bądź całkowitą zmianę intencji wnioskodawcy.

33 Uchwała nr VII/59/15 Rady Miasta w Myszkowie z dnia 7 maja 2015 r. w sprawie zasad i trybu przeprowadzania konsultacji z mieszkańcami miasta Myszkowa. 


\section{Podsumowanie}

Przyczyn prowadzenia konsultacji jest bardzo dużo. Podstawową jest to, iż konsultowanie się władz lokalnych z mieszkańcami jest obowiązkiem gremiów politycznych, a jednocześnie prawem oraz przywilejem mieszkańców. Samorządu nie tworzą jedynie władze lokalne, wprost przeciwnie - tworzą go mieszkańcy, którzy powinni aktywnie współzarządzać wspólnotą lokalną. Organy sprawujące władzę są tylko jednym z elementów samorządu, i to wcale nie najważniejszym. Władze, wykonując swoje obowiązki przedstawicielskie (ze względu na ustrój), powinny za pomocą konsultacji informować mieszkańców o ważnych kwestiach, wyjaśniając, dyskutując, spierając się i proponując rozwiązania, lecz przede wszystkim słuchając mieszkańców i licząc się z ich zdaniem. Prowadzenie konsultacji może także zapobiegać konfliktom, protestom wynikającym z nieznajomości przyczyn podjętych decyzji. Jest również ogniwem spajającym mieszkańców, pozwalającym im poznać się wzajemnie i dostrzec różnorodne potrzeby i oczekiwania. W końcu pozwoli odczuć mieszkańcom, iż są oni współodpowiedzialni za sprawy lokalne i powinni współuczestniczyć w zarządzaniu nimi. W praktyce stosowania konsultacji społecznych możemy napotkać swoistego rodzaju przeszkody wynikające $\mathrm{z}$ różnych przyczyn i tkwiące głęboko w przekonaniu władz, że uzyskanie legitymacji wyborczej pozwala na pomijanie głosów mieszkańców oraz organizacji reprezentujących różne interesy społeczne. Przeświadczenie, że mandat wyborczy pozwala decydować o wszystkim w sposób wyłączny, czyli: „skoro mnie wybrali, to ja wiem lepiej i mam pełne prawo decydować o wszystkim, nie pytając nikogo o zdanie”, ma jeszcze wielu zwolenników wśród rządzących. Stanowienie uchwał w rażący sposób łamiących prawo bądź takich, które utrudniają udział mieszkańcom w konsultacjach, jest niedopuszczalne i powinno być piętnowane przez obywateli i ich organizacje. Należy zacząć głośno o tym mówić i wskazywać błędy, niedociągnięcia oraz lekceważenie procedur przez lokalne władze. Ponadto spora część administracji publicznej charakteryzuje się niską kulturą współdziałania/współpracy z partnerami społecznymi. Przejawia się to głównie $\mathrm{w}$ nieprofesjonalnym przygotowaniu konsultacji społecznych, a nawet przeprowadzaniu ich w sposób nierzetelny, fasadowy, połowiczny. I nie zawsze wynika to z niechęci, często jest to nieumiejętność, brak przygotowania czy wiedzy. W końcu — nie są wykorzystywane informacje (opinie, propozycje) zebrane w trakcie konsultacji. Jednocześnie organizacje społeczne również bardzo często wykazują się brakiem kompetencji w zakresie współpracy, prowadzenia dialogu, niezrozumieniem istoty konsultacji i postrzeganiem ich jako negocjacji ${ }^{34}$. Wszystkie te bariery powodują, że konsultacje społeczne bywają negatywnie postrzegane przez obie strony jako rodzaj uciążliwego, długotrwałego i nieskutecznego mechanizmu.

W polskiej praktyce funkcjonowania konsultacji społecznych jest jeszcze wiele do zrobienia, lecz z całym przekonaniem można stwierdzić, że bardzo dużo już zrobiono. Przekonanie o tym, że konsultacje społeczne są ważne, potrzebne i przynoszą spore ko-

34 D. Długosz, J.J. Wygnański, Obywatele współdecydują. Przewodnik po partycypacji społecznej, Warszawa 2005, s. 20-21. 
rzyści, zaczyna kiełkować w polskim społeczeństwie, a w niektórych miejscach zakorzeniło się na dobre. Przykładów stosowania zaawansowanych form i trybów konsultacji jest wiele (Warszawa, Poznań), co niewątpliwie pokazuje, że mechanizm ten zaczyna funkcjonować jako trwały element polskiej samorządności.

\section{Bibliografia}

Długosz D., Wygnański J.J., Obywatele współdecydują. Przewodnik po partycypacji społecznej, Warszawa 2005. Europejska Karta Samorządu Lokalnego, Dz.U. z 2006 r. Nr 154, poz. 1107.

Ferens A., Drzewiński P., Olejnik M., Aktywne narzędzia i techniki prowadzenia konsultacji, [w:] Narzędzia i techniki konsultacji społecznych. Podręcznik jak prowadzić konsultacje społeczne w samorzadzie, Fundacja Rozwoju Demokracji Lokalnej Ośrodek Kształcenia Samorządu Terytorialnego im. Waleriana Pańki w Katowicach, Katowice 2013.

Kanon Lokalnych Konsultacji Społecznych, broszura pt. Regulamin konsultacji społecznych. Wytyczne, rekomendacje przykłady, Warszawa 2014.

Konsultacje społeczne - jak sprawić by byly lepsze? Propozycja Kodeksu Konsultacji i ścieżka wdrożenia, MAiC 2012.

Maszkowska A., Wenclik M., Partycypacja publiczna w województwie podlaskim - raport z badań, Białystok 2015.

Poradnik modelowej wspótpracy administracji publicznej i organizacji pozarządowych, Sieć Wspierania Organizacji Pozarządowych SPLOT, Warszawa 2011.

Rozstrzygnięcie nadzorcze Wojewody Mazowieckiego z dnia 30 września 2014 r. stwierdzające nieważność zarządzenia Wójta Gminy Bielsk nr 34/2014 z dnia 5 sierpnia 2014 r. w sprawie przeprowadzenia konsultacji społecznych dotyczących nadania nazwy dla placu/skweru położonego w części działki nr 599 w Bielsku (LEX.P.4131.34.2014.PM).

Rozstrzygnięcie nadzorcze nr NK.4.4131.166.2013 Wojewody Zachodniopomorskiego z dnia 6 marca 2013 r. stwierdzające nieważność $\$ 3$ załącznika do uchwały nr XXV/146/2013 Rady Gminy Grzmiąca z dnia 30 stycznia 2013 r. w sprawie określenia zasad i trybu konsultacji społecznych z mieszkańcami Gminy Grzmiąca (Dz.Urz.Woj. Zachodniopomorskiego, poz. 1246).

Rozstrzygnięcie nadzorcze nr NK.III.4131.1.16.2013 Wojewody Opolskiego z dnia 28 lutego 2013 r. w sprawie stwierdzenia nieważności części uchwały nr XXIII/139/13 Rady Gminy Pawłowiczki z dnia 24 stycznia 2013 r. w sprawie określenia zasad i trybu przeprowadzania konsultacji społecznych z mieszkańcami gminy Pawłowiczki (Dz.Urz. Woj. Opolskiego, poz. 607).

Rozstrzygnięcie nadzorcze nr NK-I.4131.65.2015.I Wojewody Lubuskiego z dnia 24 kwietnia 2015 r. stwierdzające nieważność części uchwały Nr VI/31/15 Rady miejskiej w Strzelcach Krajeńskich z dnia 27 marca 2015 r. w sprawie przeprowadzenia na terenie gminy Strzelce Krajeńskie konsultacji społecznych w sprawie Budżetu Obywatelskiego jako części budżetu Gminy na 2016 (Dz.Urz. Woj. Lubuskiego, poz. 832).

Rozstrzygnięcie nadzorcze nr NK.4.MN.0911-102/2007 Wojewody Zachodniopomorskiego z dnia 6 lipca 2007 r. stwierdzające nieważność $\$ 1$ ust. 4 uchwały nr VIII/84/07 Rady Miejskiej w Darłowie z dnia 19 czerwca 2007 r. w sprawie zasad i trybu przeprowadzania konsultacji z mieszkańcami miasta Darłowo.

Sześciło D., Konsultacje społeczne w gminie w świetle orzecznictwa sądów administracyjnych, „Samorząd Terytorialny" 2014, nr 1-2.

Uchwała nr LV/332/2006 Rady Powiatu Zgorzeleckiego z dnia 31 sierpnia 2006 r. w sprawie zasad i trybu przeprowadzania konsultacji z mieszkańcami powiatu zgorzeleckiego.

Uchwała nr XXXVIII/860/13 Rady Miasta Katowice z dnia 26 czerwca 2013 r. w sprawie zasad i trybów przeprowadzania konsultacji z mieszkańcami miasta Katowice. 
Uchwała nr 360/2013 Rady Miasta Zgorzelec z dnia 29 października 2013 r. w sprawie przyjęcia programu współpracy Gminy Miejskiej Zgorzelec z organizacjami pozarządowymi oraz innymi podmiotami prowadzącymi działalność pożytku publicznego w roku 2014.

Uchwała nr 848/L/2014 Rady Miasta Płocka z dnia 26 sierpnia 2014 r. w sprawie zasad i trybu przeprowadzania konsultacji społecznych na terenie miasta Płocka.

Uchwała nr VIII/88/15 Rady Miejskiej w Pabianicach z dnia 26 marca 2015 r. w sprawie zasad i trybu przeprowadzania konsultacji z mieszkańcami Miasta Pabianic oraz z organizacjami pozarządowymi i podmiotami wymienionymi w art. 3 ust. 3 ustawy z dnia 24 kwietnia 2003 r. o działalności pożytku publicznego i o wolontariacie.

Uchwała nr LXI/1691/2013 Rady Miasta Stołecznego Warszawy z dnia 11 lipca 2013 r. w sprawie zasad i trybu przeprowadzania konsultacji z mieszkańcami m.st. Warszawy.

Uchwała nr XVIII/366/15 Rady Miejskiej Wrocławia z dnia 26 listopada 2015 r. w sprawie konsultacji projektu uchwały zmieniającej uchwały w sprawie nadania statutów osiedli.

Uchwała nr VII/64/205 Rady Miasta Sopotu z dnia 27 kwietnia 2015 r. w sprawie przeprowadzenia konsultacji społecznych z mieszkańcami Sopotu dotyczących Sopockiego Programu Strategicznego na rzecz Seniorów do 2020.

Uchwała nr 508/2013 Rady Miasta Torunia z dnia 21 lutego 2013 r. w sprawie Regulaminu Konsultacji Społecznych.

Uchwała nr V/27/2011 Rady Gminy Goszczyn z dnia 29 marca 2011 r. w sprawie określenia zasad i trybu przeprowadzania konsultacji społecznych.

Uchwała nr 56/VIII/15 Rady Gminy Świerklany z dnia 3 lipca 2015 r. w sprawie zasad i trybu przeprowadzania konsultacji z mieszkańcami Gminy Świerklany.

Uchwała nr IX/22/15 Rady Gminy Rewal z dnia 6 marca 2015 r. w sprawie zasad i trybu przeprowadzania konsultacji społecznych z mieszkańcami gminy Rewal.

Uchwała nr VII/59/15 Rady Miasta w Myszkowie z dnia 7 maja 2015 r. w sprawie zasad i trybu przeprowadzania konsultacji z mieszkańcami miasta Myszkowa.

Uchwała nr XL/397/2006 Rady Powiatu Brzeskiego z dnia 26 stycznia 2006 r. w sprawie zasad i trybu przeprowadzania konsultacji z mieszkańcami Powiatu Brzeskiego (Dz. Urz. Woj. Opolskiego Nr 18, poz. 648).

Ustawa z dnia 8 marca 1990 r. o samorządzie gminnym (Dz.U. Nr 16, poz. 95 z późn. zm.).

Ustawa z dnia 5 czerwca 1998 o samorządzie powiatowym (Dz.U. Nr 91, poz. 578 z późn. zm.).

Ustawa z dnia 5 czerwca 1998 o samorządzie województwa (Dz.U. Nr 91, poz. 576 z późn. zm.).

Wyrok WSA we Wrocławiu z dnia 29 kwietnia 2011, III SA/Wr 20/11.

Wyrok WSA we Wrocławiu z dnia 10 maja 2013, III SA/Wr 140/13.

Załącznik do uchwały nr XLI/502/08 Rady Miasta Krakowa z dnia 23 kwietnia 2008 r. w sprawie zasad i trybu przeprowadzania konsultacji z mieszkańcami gminy miejskiej Kraków przy realizacji inwestycji i projektów miejskich.

Zarządzenie nr 4925/2013 Prezydenta Miasta Stołecznego Warszawy z dnia 3 września 2013 r. w sprawie określenia postępowania w Urzędzie m.st. Warszawy w związku z przeprowadzanymi konsultacjami z mieszkańcami m.st. Warszawy.

Zychowicz Z., Konsultacje społeczne w samorządzie, Szczecin 2014.

\section{Źródła internetowe}

http://www.poznan.pl/mim/main/sad-obywatelski-w-sprawie-ul umultowskiej,p,15574,21903.html.

https://mac.gov.pl/files/konsultacje-spoleczne.pdf.

http://www.kanonkonsultacji.pl/x/985571.

http://www.cismyslowice.pl/wiadomosc.php?id=75.

Wrocławskie Studia Politologiczne 21, 2016

(C) for this edition by CNS 


\section{Public consultation as a form of democratic participation in managing of local community}

Keywords: social participation, public consultations, ordinance on public consultations, governance, community social dialogue, standards of public consultations

\section{Summary}

The article discusses the issue of public consultation, legal and formal issues, used in national and European law. It shows the genesis of the Polish regulation of consultation. It presents one of the mechanisms for social participation in the local community and the opportunities offered by the use of this tool. It discusses how important it should be to consult with the people, to communicate with the public. The subject of the study is also a critical analysis of the solutions adopted in resolutions concerning the holding of consultations. At the same time particular examples of solutions used in resolutions of local government are shown. Attention is drawn to the irregularities in constructing the resolutions and the reluctance of parts of local authorities to carry out the consultations. The whole bearing was selected decisions and case law of the administrative courts. 